\title{
Diversity, ecology, biogeography and evolution of the prevalent brown algal genus Lobophora in the greater Caribbean sea, including the description of five new species
}

\author{
Vieira Christophe ${ }^{1,}{ }^{*}$, Morrow Kathleen ${ }^{2}$, D'Hondt Sofie ${ }^{1}$, Camacho Olga ${ }^{3}$, Engelen Aschwin H. ${ }^{4,5}$, \\ Payri Claude E. ${ }^{6}$, De Clerck Olivier ${ }^{1}$
}

1 Phycology Research Group and Center for Molecular Phylogenetics and Evolution Ghent University Krijgslaan 281 (S8)B-9000 Ghent , Belgium

2 Molecular, Cellular, and Biomedical Sciences University of New Hampshire Durham NH 03824, United States

${ }^{3}$ Department of Biology University of Louisiana at Lafayette Lafayette Louisiana 70504-3602, USA

${ }^{4}$ CCMAR Universidade do Algarve Campus de Gambelas 8005-139Faro, Portugal

${ }^{5}$ CARMABI Research Station Piscadera Bay Willemstad Curaçao, United States

6 UMR ENTROPIE (IRD, UR, CNRS), LabEx-CORAIL Institut de Recherche pour le Développement

B.P. A598848 Nouméa Cedex Nouvelle-Calédonie, France

* Corresponding author : Christophe Vieira,email address : cvcarp@gmail.com

\begin{abstract}
:
Distributed in tropical and warm-temperate waters worldwide, Lobophora species are found across the Greater Caribbean (i.e., Caribbean sensu stricto, Gulf of Mexico, Florida, the Bahamas, and Bermuda). We presently discuss the diversity, ecology, biogeography and evolution of the Greater Caribbean Lobophora species based on previous studies and an extensive number of samples collected across the eastern, southern and to a lesser extent western Caribbean. A total of 18 Lobophora species are now documented from the Greater Caribbean, of which five are newly described (L. agardhii sp. nov., L. dickiei sp. nov., L. lamourouxii sp. nov., L. richardii sp. nov. and L. setchellii sp. nov.). Within the Greater Caribbean, the eastern Caribbean and the Central Province are the most diverse ecoregion and province (16 spp.), respectively. Observed distribution patterns indicate that Lobophora species from the Greater Caribbean have climate affinities (i.e., warm-temperate vs. tropical affinities). Eleven Lobophora species exclusively occur in the Greater Caribbean; six are present in the western Atlantic; two in the Indo-Pacific; and one in the eastern Pacific. Biogeographic analyses support that no speciation occurred across the Isthmus of Panama, and that the Greater Caribbean acted as a recipient region for species from the IndoPacific and as a region of diversification as well as a donor region to the North-eastern Atlantic. The Greater Caribbean is not an evolutionary dead-end for Lobophora, but instead generates and exports diversity. Present results illustrate how sampling based on DNA-identification is reshaping biogeographic patterns, as we know them.
\end{abstract}

Keywords : cox3, Greater Caribbean, Eastern Caribbean, Lobophora, molecular taxonomy, Western Caribbean 
64 Abbreviations: BI, Bayesian inference; cox3, mitochondrial encoded cytochrome c oxidase III 65 gene; DNA, deoxyribonucleic acid; ML, maximum likelihood.

66

67

68

This article is protected by copyright. All rights reserved 


\section{INTRODUCTION}

70 Until recently it was assumed that the Greater Caribbean - the Caribbean sensu stricto, Gulf of

71 Mexico, Florida, the Bahamas, and Bermuda - comprised only one species of the brown algal

72 genus Lobophora, L. variegata, whose holotype was collected from the "West Indies",

73 presumably from Guadeloupe (Vieira et al. 2016). Further species identifications were never

74 explored after the first Lobophora species description as Dictyota variegata, later interpreted as

75 displaying different morphological forms (e.g., crust, decumbent, ruffled and erect forms; De

76 Ruyter van Steveninck et al. 1988, Littler and Littler 2000). However, J.V.F. Lamouroux's actual

77 interpretation was "exhibiting different colors longitudinally" (“longitudinaliter variegatâ";

78 Lamouroux 1809). Lobophora variegata presented not only different morphotypes but also

79 inhabited several ecological niches. This erroneous taxonomic interpretation is now acknowledged

80 two centuries later, with the help of DNA sequencing (Vieira et al. 2016). Sun et al. (2012), Vieira

81 et al. (2014) and Camacho et al. (2019) demonstrated that different morpho- or eco-types represent

82 different species. Sun et al. (2012) were the first to sequence a Lobophora specimen from the

83 Caribbean s.s. (Curaçao, Netherland Antilles), but did not assign it to the specific epithet $L$.

84 variegata, implicitly suggesting that more than one species occurred in the Greater Caribbean.

85 Schultz et al. (2015) followed by Vieira et al. (2016, 2017) and Camacho et al. (2019)

86 subsequently confirmed that the diversity in the Greater Caribbean was much higher than

87 previously assumed (Table 1, Fig. 1) with the report of nine (Schultz et al. 2015) and five

88 (Camacho et al. 2019) additional species, bringing the number of known species in this region to

8915 (Table 1). Identifying more than one species raised the question, which of these Greater

90 Caribbean species was the genuine L. variegata. After some debate, L. variegata was finally

91 identified as a species geographically restricted to a part of the Greater Caribbean including so far

92 Mexico (Quintana Roo), Bahamas, Florida Keys, Grand Cayman, Guadeloupe, Jamaica and St

93 Kitts and Nevis (Vieira et al. 2016, Godínez-Ortega et al. 2018, Camacho et al. 2019), based on

94 molecular and morphological evidence established from type material (Vieira et al. 2016).

95 Lobophora is found across the Greater Caribbean, in warm temperate and tropical regions, with

96 the northernmost distribution of L. dispersa at Cape Lookout, North Carolina (34²3'34.6" N;

97 Camacho et al. 2019). The increasingly detailed distribution data from the Greater Caribbean

98 enables us to redraw species distribution and diversity patterns within this region.

99 Complementing previous taxonomic efforts on the genus Lobophora in the Greater

100 Caribbean, the present study aims to: (1) test completeness of our current knowledge on diversity

This article is protected by copyright. All rights reserved 
101 by expanding the sampling to the eastern, southern and western Caribbean, (2) examine to what

102 extent the distribution patterns of Lobophora spp. reflect currently defined biogeographic regions,

103 (3) examine range sizes of Lobophora spp. from the Greater Caribbean at regional- and global-

104 scales, and (4) discuss the evolution of the Greater Caribbean Lobophora species.

105

106 MATERIAL AND METHODS

107 Sampling localities

108 Sampling was performed in the framework of several campaigns in the Lesser Antilles (French

109 and Dutch Caribbean) and Belize (Fig. 1, Tables S1, S2 in the Supporting Information). Thirty-

110 seven Lobophora specimens were collected by SCUBA between 0 and $30 \mathrm{~m}$ depth, in the Lesser

111 Antilles (Antigua, Bequia, Guadeloupe, Martinique, Saba, Saint Barthelemy, Saint Lucia, Saint

112 Martin, Saint Vincent) in 2015 during the PACOTILLES research expedition (April 21 to May 10,

113 and May 13 to June 2, 2015), with the IRD N/O ANTEA research vessel. Over one thousand

114 specimens were collected around Curaçao (Netherland Antilles, February 3 and 16, 2017), of

115 which 126 specimens were selected based on their morphology and habitat for DNA sequencing.

116 Another 156 specimens were collected haphazardly from other Dutch and French Antilles islands

117 (i.e., Bonaire, Saba, Saint Barthelemy, Saint Martin, Sint Eustatius) and in Belize. Specimens were

118 preserved in silica gel for DNA sequencing, and herbarium specimens were mounted and later

119 deposited in either the Herbarium of the Botanic Garden Meise in Belgium (BR) or the Herbarium

120 of New Caledonia (NOU) registered in the Index Herbariorum (Thiers 2020).

\section{Molecular and morphological analyses}

123 Total genomic DNA was extracted from tissue samples dried in silica gel using a cetyl-trimethyl

124 ammonium bromide (CTAB) extraction method. Sequences were generated from the

125 mitochondrial encoded cytochrome c oxidase III gene (cox3), the most commonly used barcode

126 marker for this genus (Vieira et al. 2014, 2016), following Vieira et al. (2014). New sequences

127 were added to the datasets from Vieira et al. (2016) and Camacho et al. (2019), and aligned using

128 MUSCLE (Edgar 2004). Phylogenetic trees were reconstructed using Bayesian (BI) and maximum

129 likelihood (ML) methods based on the mitochondrial cox3 gene following Vieira et al. (2016).

130 Morphological observations of Lobophora specimens included analyses of the external and

131 internal structures of the specimens following Vieira et al. (2014).

132

This article is protected by copyright. All rights reserved 


\section{Biogeographic analyses}

134 We used Robertson and Cramer (2014) provinces and Spalding et al. (2007) ecoregions to look

135 into Lobophora diversity patterns in the Greater Caribbean at large and fine spatial scales. We

136 performed hierarchical clustering analyses to determine how these ecoregions and provinces relate

137 to each other. We investigated if the biogeographic scheme proposed by Robertson and Cramer

138 (2014; three provinces delimited based on the distribution of shore-fish fauna of the Greater

139 Caribbean) is reflected in the distribution patterns of Lobophora. To determine how the provinces

140 and ecoregions relate to each other two commonly used hierarchical clustering methods were

141 performed, i.e., the Euclidean distance with Ward's clustering method, and the Jaccard index with

142 the unweighted pair-group method with arithmetic averages (UPGMA). Analyses were performed

143 using the R package FactoMineR (Lê et al. 2008).

144

145 RESULTS

146 Molecular phylogenetic analyses

147 Sequence data was generated for 325 specimens. Specimens collected in this study positioned in

14816 highly supported lineages in ML and BI analyses (Figs. 2, S1 in the Supporting Information).

149 Of these 16 lineages, 13 were previously reported from the Greater Caribbean by Schultz et al.

150 (2015), Camacho et al. (2019) and Vieira et al. (2016) including nine described: Lobophora

151 canariensis, L. colombiana, L. declerckii, L. delicata, L. dispersa, L. guadeloupensis, L.

152 littlerorum, L. schneideri, L. variegata; and four undescribed species: L. spWA02, L. sp64, $L$.

$153 \mathrm{sp} 85$, L. sp86. An additional species recently described from Cape Verde, L. caboverdeana (Vieira

154 et al. 2019b), is reported from the Greater Caribbean for the first time. In addition, two lineages

155 are newly reported for the Caribbean, $L$. sp10, previously reported from Kavieng, Papua New

156 Guinea (Vieira et al. 2019a), and L. sp90, reported for the first time from the Greater Caribbean.

157 We formally describe five new species (Tables 2, 3; Figs. 3, 4), previously identified using

158 sequence-based species delineation methods (Generalized Mixed Yule Coalescent, Automatic

159 Barcode Gap Discovery, Poisson Tree Processes) by Schultz et al. (2015), Vieira et al. (2017) and

160 Camacho et al. (2019; i.e., L. sp10, L. sp64, L. sp85, L. sp86 and L. spWA02). We also provide a

161 more detailed description of $L$. variegata. The remaining lineage $L$. sp90 is not formally described

162 here because we lack enough material at present.

163

164 Distribution

This article is protected by copyright. All rights reserved 
165 We examined the distribution of Lobophora species within the Greater Caribbean (Fig. 5) at two

166 geographic scales, i.e., ecoregion-level (Fig. 5; Spalding et al. 2007) and province-level (Fig. 5;

167 Robertson and Cramer 2014). No species was found in all ecoregions, but L. declerckii, L.

168 schneideri and L. dispersa were present in all three provinces (Fig. 5). The last is the only species

169 reported from the Carolinian ecoregion so far. Additionally, L. declerckii, reported from Belize,

170 Curaçao, Saba, Saint Croix, Saint Lucia and Sint Eustatius, stands out as the most widespread

171 species in the Greater Caribbean. Lobophora tortugensis O.Camacho \& Fredericq was only found

172 in the Northern Province. Twelve species were at least present in two provinces, and mainly the

173 Central and Southern Provinces. Confined to the Greater Caribbean, L. variegata was further

174 reported from the Dominican Republic, and appears to be restricted to Mexico (Quintana Roo),

175 Florida (Florida Keys), the Bahamas, and the Lesser and Greater Antilles.

176

\section{Biogeographic analyses}

178 Regionalization within the Greater Caribbean based on the ecoregions was performed using two 179 hierarchical clustering methods (Fig. 6; Jaccard/UPGMA and Euclidean/Ward). The clustering of 180 regions varied to some extent according to the methods used. The Euclidean Ward HC method 181 presented the highest cophenetic correlation coefficient $(\mathrm{CP}=0.8135)$. The Euclidean/Ward HC 182 and Jaccard/Ward methods concordantly combined the following ecoregions: Carolinian and 183 southern Gulf of Mexico; Floridian and northern Gulf of Mexico; Bahamian and Greater Antilles; 184 eastern Caribbean, southern Caribbean and Bermuda. In the latter case, the methods diverged in 185 the relationships among the three ecoregions. These methods showed inconsistence in the 186 placement of the western Caribbean and southwest Caribbean. Except for the presence of the 187 southwest Caribbean, clustering of the Floridian, northern and southern Gulf of Mexico, and 188 Carolinian corresponds to the Northern Province of Robertson and Cramer (2014). Spalding et al. 189 (2007) does not include the Floridian in the Greater Caribbean warm-temperate region. In the two 190 analyses the ecoregions composing the Central Province of Robertson and Cramer (2014) do not 191 cluster together. Furthermore the southern Caribbean, part of the Southern Province of Robertson 192 and Cramer (2014), clusters with the eastern Caribbean and Bermuda in both analyses.

193 Eleven Lobophora species exclusively occur in the Greater Caribbean (Fig. 5), six are 194 shared with other regions in the Atlantic (L. caboverdeana, L. canariensis, L. delicata, L. dispersa, 195 L. littlerorum, L. schneideri), two are shared with the Indo-Pacific (L. dispersa and L. setchellii sp. 196 nov.), and one is shared with the eastern Pacific (L. schneideri; Clipperton Island). The last, 
197 however, could be an introduction (Vieira et al. 2018). Lobophora dispersa is not only found

198 across the Greater Caribbean, but also across the Atlantic (Macaronesia, Brazil) and in the

199 southwestern Indo-Pacific (Madagascar, South Africa). Reported across the Indo-Pacific (Juan de

200 Nova, Kavieng, Tuvalu), L. setchellii sp. nov. displays a broad distribution spanning three Oceans

201 (Atlantic, Indian and Pacific Oceans).

202

\section{DISCUSSION}

\section{Diversity patterns}

205 This is the third major taxonomic study of the genus Lobophora in the Greater Caribbean and the 206 first largest sampling in the eastern, southern and western Caribbean (Belize). Of the 16 species

207 recognized in this study, 13 were previously reported in the Greater Caribbean, and three species

208 (L. caboverdeana, L. setchellii sp. nov., L. sp90) were newly identified from this region. These

209 new data bring the total number of known species in the Greater Caribbean to 18, and to 19 in the

210 Atlantic. Interestingly the diversity now confirms a previous estimate of 18 species in the Atlantic

211 by Vieira et al. (2017). This study confirms that the Greater Caribbean and more broadly the

212 Atlantic with 18 species is far less diverse than the Indo-Pacific with 95 species (Vieira et al.

213 2017). The Greater Caribbean stands out as a diversity hotspot for Lobophora in the North 214 Atlantic Ocean.

215 The eastern Caribbean is the most diverse ecoregion from the Greater Caribbean with 16

216 species. This is also in line with the theory that the first Caribbean Lobophora species came

217 exclusively from the Indo-Pacific - and not from the eastern Pacific - by founder events, leading

218 to additional speciation events in this region (Vieira et al. 2017). Alternatively, these results may

219 also be due to a larger sampling effort in this ecoregion. On a broader scale, the Central Province

220 sensu Robertson and Cramer (2014) is the most diverse region with 16 species followed by the

221 Southern Province with 10 species. With only 6 species, the diversity in the Northern Province,

222 which is a warm-temperate region, is two to threefold lower than the other two provinces. This

223 lower diversity is likely due to the lower temperature $\left(<25^{\circ} \mathrm{C}\right)$, which is unsuitable for most

224 Lobophora species with tropical affinities.

226 Biogeography

227 Contrary to previous ideas associated with the name Lobophora variegata - considered to be a 228 widespread species -, most likely not all Greater Caribbean Lobophora species are present across 
229 this region. Some species appear more widespread than others, and L. variegata as far as we know

230 is restricted to the Floridian, Bahamian, western Caribbean, Greater Antilles and eastern

231 Caribbean ecoregions. Only three species are present across the Greater Caribbean (i.e., Southern,

232 Central and Northern Provinces; L. declerckii, L. dispersa and L. schneideri). Eight species are

233 restricted to the Central and Southern Provinces (tropical region), and only one species was

234 exclusively found in the Northern Province, L. tortugensis (Fig. 5).

235 Observed distribution patterns indicate that Lobophora species from the Greater Caribbean

236 have climate affinities. Of the 18 Greater Caribbean Lobophora species, four clearly have warm-

237 temperate affinities, namely L. delicata, L. dispersa, L. schneideri and L. tortugensis. Rare in the

238 tropical Greater Caribbean (reported in the eastern and southwest Caribbean), L. schneideri is a

239 common species in the Canary Islands (warm-temperate climate) where it can dominate benthic

240 assemblages, as well as in the eastern Mediterranean Sea (Vieira et al. 2018). Common in the

241 temperate Greater Caribbean (i.e., Northern Province), L. dispersa was previously reported from

242 warm-temperate localities (South Africa, Madagascar and the Canary Islands). Lobophora

243 tortugensis was only reported from the Northern Province in the Greater Caribbean. The other 14

244 species present tropical affinities, and L. declerckii stands as the most common species in the

245 tropical Greater Caribbean and was recorded at the southern edge of the Northern Province in the

246 Floridian ecoregion. Restrictions to either warm-temperate or tropical regions reflect differences

247 in physiological tolerance among species. Cold adaptation is a process with little success for

248 members of the genus Lobophora as demonstrated by the limited number of species that have

249 adapted to temperate conditions over evolutionary time (Vieira et al. 2017) in comparison to other

250 Caribbean taxa such as Dictyota (Dictyotales, Phaeophyceae; Tyberghein 2012).

251 The hierarchical analyses performed based on Spalding et al.'s (2007) 11 ecoregions do not

252 support the biogeographic scheme proposed by Robertson and Cramer (2014) for Lobophora,

253 except for within the Northern Province. The ecoregions composing the Central and Southern

254 Provinces do not cluster together based on Lobophora distribution patterns. Bermuda and the

255 eastern and southern Caribbean form a separate province; Bahamian, Greater Antilles and western

256 Caribbean another province (Central Province) and finally Floridian, northern and southern Gulf

257 of Mexico and Carolinian would form a northern province in agreement with Robertson and

258 Cramer (2014). The placement of the southwest Caribbean comes as a surprise. Nevertheless, the

259 unequal sampling across these ecoregions possibly explains some of these patterns, which could

260 explain why the southwest Caribbean clusters with the Northern Province ecoregions.

This article is protected by copyright. All rights reserved 
With two-thirds of Lobophora diversity restricted to the Greater Caribbean, this region

262 forms an isolated hotspot in the Atlantic for this genus. The rest of the Greater Caribbean diversity

263 is mainly shared with the rest of the Atlantic. We discuss in the final section the reasons

264 explaining this pattern.

\section{Morphology and ecology}

267 Previous authors recorded three main growth forms associated to the name "Lobophora

268 variegata", namely, encrusting, decumbent and ruffled (De Ruyter van Steveninck and Breeman

269 1987, Coen and Tanner 1989, Littler and Littler 2000). We now know that there is a continuum of

270 morphological habits, ranging from crustose to stipitate, with each species displaying a

271 predominant morphotype (Vieira et al. 2014, Camacho et al. 2019). We classified each species

272 from the Greater Caribbean based on their morphology and ecology (Table 4). The morphotypes

273 described from the Indo-Pacific are found in the Greater Caribbean, and several trends with regard

274 to the evolutionary signal of morphological characters or habit stand out (Vieira et al. 2014).

275 Populations of Lobophora were previously reported from various habitats in the Greater

276 Caribbean (e.g., coral reefs, mangrove, seagrass and macroalgal beds; e.g., Coen and Tanner 1989)

277 and at different depths from the intertidal to $135 \mathrm{~m}$ depth (Schultz et al. 2015). They grow in calm

278 to agitated waters, in low to high fish grazing zones, and on biotic and abiotic substrates. One

279 population was reported dominating the mesophotic benthic cover in the Bahamas at $90 \mathrm{~m}$ (Littler

280 et al. 1986). Similar ecological habits are found in the Greater Caribbean as in the Indo-Pacific

281 (Vieira et al. 2014; Table 3). As previously noted, notably in Belize (Coen and Tanner 1989,

282 Littler and Littler 2000), some morphotypes/species are associated with specific habitats (Table 4).

283 However, while the situation in Belize may provide an example of clear habitat specialization

284 between three doubtlessly distinct and conspicuous species, several Lobophora species from the

285 Greater Caribbean adopt very similar ecological habits and largely co-exist. They grow along a

286 wide depth range, in similar habitats, under similar conditions (Table 4). Some species have

287 greater affinities for specific habitats, but they can also be found in other habitats growing next to

288 other Lobophora species. However, while several species may be found growing adjacent to each

289 other (e.g., L. declerckii and L. canariensis) they occupy distinct niches. For example, $L$.

290 canariensis forms small procumbent blades in shaded areas, while L. declerckii forms large shelf-

291 like blades fully exposed to the light. Microhabitat locality allows multi-species coexistence.

292 Furthermore, Lobophora species can coexist because many are extremely rare, possibly as a result

This article is protected by copyright. All rights reserved 
293 of limited recruitment opportunities, which limits competition. Predation may also regulate 294 populations of more palatable species. Other than L. declerckii, which can form extensive cover, 295 intra- and inter-specific competition is limited for most Lobophora species.

296 Lobophora is known in the Caribbean for proliferating on damaged reefs following 297 environmental and biological disturbances, by forming dense mats over dead corals (Vieira 2019). 298 Most Lobophora species are rather discrete benthic macroalgae in the Greater Caribbean 299 ecosystems. Some species can grow basally on coral branches (e.g., L. littlerorum on Porites), but 300 such species are sparsely distributed, and do not form extensive populations (A.H. Engelen, 301 C.Vieira, pers. obs.). Only a few species, most notably L. declerckii, can cover large areas on coral 302 reefs across the Greater Caribbean. Bloom-forming species are more likely to cause shifts from 303 coral to Lobophora dominance following disturbances on reefs (Vieira 2019). In this sense, $L$.

304 declerckii is very likely the main species concerned in Lobophora-coral phase shifts in the Greater 305 Caribbean. The ecological success and the widespread distribution of $L$. declerckii may be

306 explained by the capacity of this species to form extensive cover. Considering the ecological 307 differences among Lobophora species including their ability to form blooms and to outcompete 308 corals, future studies need to describe the taxonomy of the species of Lobophora (using molecular 309 methods) that compete with corals and that are implicated in coral-algal phase shifts (Vieira 310 2019).

312 The Greater Caribbean: an evolutionary dead-end?

313 With no less than 11 species restricted to the Greater Caribbean (Lobophora agardhii, L.

314 colombiana, L. crispata, L. declerckii, L. dickiei, L. guadeloupensis, L. lamourouxii, L. richardii, 315 L. tortugensis, L. variegata and L. sp90), this region of the Atlantic is characterized by a high level 316 of endemism for the genus Lobophora (i.e., ca. two-thirds of the Greater Caribbean Lobophora 317 species diversity). Another five species are distributed across the northern Atlantic, namely $L$. 318 caboverdeana, L. canariensis, L. delicata, L. littlerorum and L. schneideri. The remaining two 319 species have a western Indo-Pacific - Atlantic distribution, L. dispersa (Camacho et al. 2019, 320 Vieira et al. 2019b) and L. setchellii sp. nov. (Vieira et al. 2019a). Additional molecular analyses 321 are recommended to determine if the broad distribution of $L$. setchellii, which spans three Oceans 322 (Atlantic, Indian and Pacific Oceans), is the result of multiple introductions, or alternatively if this 323 cosmopolitan species constitutes a species complex. 
Lobophora diversity in the Caribbean resulted mainly from repeated establishments at

325 different periods by phylogenetically distant lineages (Vieira et al. 2017). These rare events of

326 dispersal from the Indo-Pacific to the Caribbean were followed by isolation and speciation,

327 causing a high-level of endemism in this region. Given that no sister species of Lobophora have

328 been identified between the eastern Pacific and the Greater Caribbean, we conclude that the

329 formation of the Isthmus of Panama (i.e., the closing of the Central American Seaway) did not

330 result in vicariant speciation events. It is nevertheless possible that, similarly to certain groups

331 such as foraminifera, Lobophora lineages present in the eastern Pacific following the closure of

332 Central American Seaway became extinct as a result of sea temperature decline due to increased

333 coastal upwelling (Chaisson \& Ravelo 2000, O’Dea et al. 2016). Four to five Lobophora

334 diversification events occurred in the Greater Caribbean: the clades of sister species L. variegata-

335 L. richardii, L. crispata-L. guadeloupensis, L. schneideri-L. delicata and L. lamourouxii-L.

336 caribica. Considering the broader distribution of the clade L. schneideri-L. delicata across the

337 North Atlantic, it is possible that diversification of this clade occurred somewhere else in the

338 North Atlantic and was followed by range expansion.

339 The patterns of distribution observed in the Atlantic lead us to the conclusion that the

340 eastern Atlantic represents a subset of diversity from the western Atlantic, possibly as a result of

341 range expansion. Similar patterns of distribution were observed in other macroalgae, e.g., Dictyota

342 crenulata (Tronholm et al. 2013), Laurencia (Hernández et al. 2017) Halimeda (Verbruggen et al.

343 2009), Cladophoropsis membranacea (Kooistra et al. 1992).

344 The high level of endemism observed in the Greater Caribbean in Lobophora ( $60 \%$

345 endemism) is also found in other Dictyotales (e.g., in Padina and Dictyota; Tronholm et al. 2013,

346 Silberfeld et al. 2014). The inclusion of molecular data may explain why these numbers contrast

347 with the generally low level of endemism characterizing the Greater Caribbean based on public

348 databases (30\% endemism; Costello et al. 2017), and thus stresses the importance of using

349 molecular taxonomic approaches to accurately assess levels of endemism.

\section{CONCLUSIONS}

352 For more than 200 years, phycologists incorrectly assigned the morphological and ecological

353 diversity of the genus Lobophora to a single species. Here we add to the growing body of

354 evidence that there are numerous species, and that the Greater Caribbean accounts for at least 18, 355 including 11 endemic species. While some parts of the Greater Caribbean deserve further 
356 attention, e.g., the Bahamas, Greater Antilles (e.g., Cuba), western part of the Gulf of Mexico and

357 the western Caribbean, we have gained a better perspective on Lobophora diversity, ecology and

358 distribution within this region. The increasing number of molecular and geographic studies on

359 Lobophora makes this brown algal genus a good candidate model for biogeographic and

360 evolutionary studies in the future. Finally this study illustrates how sampling based on DNA-

361 identification is reshaping biogeographic patterns, as we know them.

362

\section{Acknowledgements}

364 Ghent University is acknowledged for a BOF postdoctoral fellowship for Christophe Vieira. We 365 thank the collectors that contributed to the assembly of this dataset: Renate Oli and Pam 366 Engelberts for collecting samples in the Netherlands Antilles and Ester Serrão for collecting 367 samples in the Dominican Republic. We thank Mark Vermeij and CARMABI for facilitating this 368 study. This work makes use of resources and facilities provided by Gent University as part of the 369 Belgian contribution to EMBRC-ERIC (FWO GOH3817N). Part of the samples were collected 370 during the French scientific campaign PACOTILLES in 2015 (DOI, https://doi.org//10.17600/ 371 15005200) onboard the vessel Antea. This study received Portuguese national funds from FCT 372 Foundation for Science and Technology through project UID/Multi/04326/2019. 


\section{References:}

376 Camacho, O., Fernández-García, C., Vieira, C., Gurgel, C.F.D., Norris, J., Freshwater, D.W. \& Fredericq, S. 2019. The systematics of Lobophora (Dictyotales, Phaeophyceae) in the

378 western Atlantic and eastern Pacific oceans: eight new species J. Phycol. 55:611-624.

379 Chaisson, W. \& Ravelo, A. 2000. Pliocene development of the east-west hydrographic gradient in 380 the equatorial Pacific. Paleoceanography 15:497-505.

381 Coen, L. \& Tanner, C. 1989. Morphological variation and differential susceptibility to herbivory 382 in the tropical brown alga Lobophora variegata. Mar. Ecol. Prog. Ser. 54:287-298.

383 Costello, M.J., Tsai, P., Wong, P.S., Cheung, A.K.L., Basher, Z. \& Chaudhary, C. 2017. Marine 384 biogeographic realms and species endemicity. Nat. Commun. 8:1057.

385 De Ruyter van Steveninck, E. \& Breeman, A. 1987. Deep water populations of Lobophora 386 variegata (Phaeophyceae) on the coral reef of Curaçao: influence of grazing and dispersal on distribution patterns. Mar. Ecol. Prog. Ser. 38:241-250.

388 De Ruyter van Steveninck, E., Kamermans, P. \& Breeman, A. 1988. Importance of physical and 389 biological processes in structuring tropical intertidal populations of Lobophora variegata 390 (Phaeophyceae). Mar. Ecol. Prog. Ser. 44:77-84.

391 Edgar, R.C. 2004. MUSCLE: multiple sequence alignment with high accuracy and high $392 \quad$ throughput. Nucleic Acids Res. 32:1792-7.

393 Godínez-Ortega, J.L., Cabrera, L.I., Garcia-Sandoval, R., Wynne, M.J., Olivares-Rubio, H.F., 394 Ramirez-Garcia, P. \& Granados-Barba, A. 2018. Morphological and molecular 395 characterization of Lobophora declerckii and L. variegata (Dictyotales, Ochrophyta) on 396 the Atlantic coast of Mexico. Phytotaxa 382:57-73.

397 Hernández, O.E., Sentíes, A., Dreckmann, K.M., Cassano, V. \& Fujii, M.T. 2017. Species 398 diversity and biogeographical patterns of Laurencia sensu stricto (Rhodophyta) in the 399 Atlantic Ocean. Hidrobiológica 27:301-14.

400 Kooistra, W.H., Stam, W.T., Olsen, J.L. \& van den Hoek, C. 1992. Biogeography of $401 \quad$ Cladophoropsis membranacea (Chlorophyta) based on comparisons of nuclear rDNA ITS 402 sequences. J. Phycol. 28:660-8.

403 Lê, S., Josse, J. \& Husson, F. 2008. FactoMineR: an R package for multivariate analysis. J. Stat. 404 25:1-18. 
405 Littler, D.S. \& Littler, M.M. 2000. Caribbean reef plants. An identification guide to the reef plants of the Caribbean, Bahamas, Florida and Gulf of Mexico. Offshore Graphics Inc., Washington DC, $542 \mathrm{pp}$.

408 Littler, M.M., Littler, D.S., Blair, S.M. \& Norris, J.N. 1986. Deep-water plant communities from 409 an uncharted seamount off San Salvador Island, Bahamas: distribution, abundance, and 410 primary productivity. Deep-Sea Res. Pt. I. 33:881-92.

411 O’Dea, A., Lessios, H.A., Coates, A.G., Eytan, R.I., Restrepo-Moreno, S.A., Cione, A.L., Collins, 412 L.S., De Queiroz, A., Farris, D.W. \& Norris, R.D. 2016. Formation of the Isthmus of 413 Panama. Sci. Adv. 2:e1600883.

414 Robertson, D.R. \& Cramer, K.L. 2014. Defining and dividing the greater Caribbean: insights from 415 the biogeography of shorefishes. PLOS ONE 9:e102918.

416 Schultz, N.E., Lane, C.E., Le Gall, L., Gey, D., Bigney, A.R., De Reviers, B., Rousseau, F. \& 417 Schneider, C.W. 2015. A barcode analysis of the genus Lobophora (Dictyotales, 418 Phaeophyceae) in the western Atlantic Ocean with four novel species and the 419 epitypification of L. variegata (J.V. Lamouroux) E.C. Oliveira. Eur. J. Phycol. 50:1-20. 420 Silberfeld, T., Bittner, L., Fernández-García, C., Cruaud, C., Rousseau, F., Reviers, B., Leliaert, 421 F., Payri, C.E. \& De Clerck, O. 2014. Species diversity, phylogeny and large scale 422 biogeographic patterns of the genus Padina (Phaeophyceae, Dictyotales). J. Phycol. $423 \quad 49: 130-42$.

424 Spalding, M.D., Fox, H.E., Allen, G.R., Davidson, N., Ferdaña, Z.A., Finlayson, M., Halpern, 425 B.S., Jorge, M.A., Lombana, A. \& Lourie, S.A. 2007. Marine ecoregions of the world: a 426 bioregionalization of coastal and shelf areas. Bioscience 57:573-83.

427 Sun, Z., Hanyuda, T., Lim, P.E., Tanaka, J., Gurgel, C.F.D. \& Kawai, H. 2012. Taxonomic 428 revision of the genus Lobophora (Dictyotales, Phaeophyceae) based on morphological 429 evidence and analyses $r b c \mathrm{~L}$ and cox3 gene sequences. Phycologia 51:500-12. 430 Thiers B. 2020. Index Herbariorum: A global directory of public herbaria and associated staff. 431 New York Botanical Gardens Virtual Herbarium, New York, NY, US. Available at: 432 http://www.givd.info.

433 Tronholm, A., Afonso-Carrillo, J., Sansón, M., Leliaert, F., Fernández-García, C. \& De Clerck, O. 434 2013. Taxonomy of the Dictyota ciliolata-crenulata complex (Dictyotales, 435 Phaeophyceae). Phycologia 52:171-81. 
436 Tyberghein, L. 2012. Evolution, diversity and niche dynamics of seaweeds. Ph.D. dissertation, Ghent University, Ghent, 185 pp.

438 Verbruggen, H., Tyberghein, L., Pauly, K., Vlaeminck, C., Nieuwenhuyze, K.V., Kooistra, W.H.,

439 Leliaert, F. \& De Clerck, O. 2009. Macroecology meets macroevolution: evolutionary 440 niche dynamics in the seaweed Halimeda. Global. Ecol. Biogeogr. 18:393-405.

441 Vieira, C. 2020. Lobophora-coral interactions and phase shifts: summary of current knowledge $442 \quad$ and future directions. Aquat. Ecol. 54:1-20.

443 Vieira, C., Aharonov, A., Paz, G., Tsiamis, K., Engelen, A., Einav, R. \& De Clerck, O. 2018.

444 Diversity and origin of the genus Lobophora in the Mediterranean Sea including the 445 description of two new species. Phycologia 58:163-8.

446 Vieira, C., Camacho, O., Sun, Z., Fredericq, S., Leliaert, F., Payri, C. \& De Clerck, O. 2017.

447 Historical biogeography of the highly diverse brown seaweed Lobophora (Dictyotales,

448 Phaeophyceae). Mol. Phylogen. Evol. 110:81-92.

449 Vieira, C., Camacho, O., Wynne, M.J., Mattio, L., Anderson, R., Bolton, J.J., Sansón, M., 450 D'Hondt, S., Leliaert, F., Fredericq, S., Payri, C. \& De Clerck, O. 2016. Shedding new

$451 \quad$ light on old algae: matching names and sequences in the brown algal genus Lobophora 452 (Dictyotales, Phaeophyceae). Taxon 65:689-707.

453 Vieira, C., D'hondt, S., De Clerck, O. \& Payri, C.E. 2014. Toward an inordinate fondness for stars, 454 beetles and Lobophora? Species diversity of the genus Lobophora (Dictyotales, 455 Phaeophyceae) in New Caledonia. J. Phycol. 50:1101-19.

456 Vieira, C., De Clerck, O., Millet, L. \& Payri, C.E. 2019a. Description of 10 new Lobophora 457 species from the Bismarck Sea (Papua New Guinea). Phycol. Res. 67:228-38.

458 Vieira, C., Henriques, F., D'hondt, S., Neto, A.I., Almada, C.H., Kaufmann, M., Sansón, M., 459 Sangil, C. \& De Clerck, O. 2019b. Lobophora (Dictyotales) species richness, ecology and 460 biogeography across the North-eastern Atlantic archipelagos. J. Phycol. doi: 10.1111/jpy.12956.

464 Figure 1. Map of sampling localities in the Greater Caribbean from previous (Sun et al. 2012, 465 Schultz et al. 2015, Camacho et al. 2019) and current studies. The regions correspond to 466 Robertson and Cramer (2014) provinces. 
468 Figure 2. Phylogenetic tree of the genus Lobophora using Bayesian method, generated with 469 MrBayes v3, and based on cox3 sequences. The values shown at each node represent posterior 470 probabilities. A black filled circle represents full support. Two species from the Greater Caribbean 471 were not identified in our study, L. crispata, for which no cox3 sequences are available, and $L$. 472 tortugensis indicated by a star in the tree.

473

474 Figure 3. Habit photographs of some Lobophora species from the Greater Caribbean and 475 herbarium pictures. Lobophora canariensis from Saint Lucia, voucher CP15460 (A); L. declerckii 476 from Saint Lucia, voucher CP15434 (B); L. dickiei sp. nov. from Martinique, voucher CP15086 477 (C); L. guadeloupensis from Curaçao, voucher CWV0822 (D); L. lamourouxii sp. nov. from Saint 478 Vincent, voucher CP15164 (E); L. richardii sp. nov. from Martinique, voucher CP15127 (F); L. 479 variegata from Saint Martin, voucher CP15730 (G); L. colombiana from Bequia, voucher 480 CP15268 (H); L. setchellii sp. nov. from Saint Vincent, voucher CP15174 (I). Photographs of 481 holotype of new species and of L. variegata from Saint Martin: L. agardhii, voucher CP15811 (J); 482 L. dickiei, voucher CP15473 (K; the black arrow shows L. dickiei at the base of Avrainvillea 483 nigricans); L. lamourouxii, voucher CP15166 (L); L. richardii, voucher CP15127 (M); L. 484 setchellii, voucher CP15174 (N); L. variegata, voucher CP15729 (O).

485

486 Figure 4. Transverse (up) and longitudinal (down) sections of thallus of new Lobophora species 487 from the Greater Caribbean. L. agardhii sp. nov. from Saint Martin, voucher CP15811 (A); L. 488 caboverdeana from Bequia, voucher IRD11180 (B); L. dickiei sp. nov. from Martinique, voucher 489 CP15473 (C); L. lamourouxii from Saint Vincent, voucher CP15164 (D); L. richardii from 490 Martinique, voucher CP15127 (E); L. setchellii sp. nov. from Saint Vincent, voucher CP15174 491 (F); L. sp90 from Saint Vincent, voucher CP15183 (G); L. variegata from Saint Martin, voucher 492 CP15729 (H).

493

494 Figure 5. Lobophora species diversity map per provinces (upper map) according to Robertson and 495 Cramer (2014) and ecoregions (lower map) according to Spalding et al. (2007). The table on the 496 right lists the presence of the 18 Lobophora species from the Greater Caribbean per ecoregion and 497 provinces.

498

499 Figure 6. Dendrograms and maps resulting from UPGMA hierarchical clustering of ecoregion (A) 500 and provinces (B) species assemblages based on similarity matrix computed with Jaccard 501 coefficient for Lobophora.

This article is protected by copyright. All rights reserved 
TABLE 1. List of the 15 Lobophora species from the Greater Caribbean prior this study and the countries of collections. ${ }^{(1)}$ L. sp65 in Vieira et al. (2016), ${ }^{(2)}$ L. sp78 in Vieira et al. (2016), ${ }^{(3)}$ WA04 in Schultz et al. (2015) and L. sp40 in Vieira et al. (2016), ${ }^{(4)} L$. sp44 in Vieira et al. (2016), ${ }^{(5)} L$. sp39 in Vieira et al. (2016) and L. variegata in Schultz et al. (2015), ${ }^{(6)}$ WA02 in Schultz et al. (2015), (7) WA03 in Schultz et al. (2015), ${ }^{(8)}$ WA01 in 507 Schultz et al. (2015), ${ }^{(9)}$ L. sp77 in Vieira et al. (2016).

\begin{tabular}{|c|c|c|c|c|c|c|c|c|c|c|c|c|c|c|c|}
\hline & 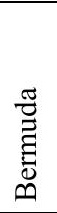 & 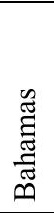 & $\begin{array}{l}\frac{\pi}{0} \\
\frac{0}{0} \\
\frac{0}{0}\end{array}$ & $\begin{array}{l}\frac{\pi}{2} \\
\frac{\pi}{2} \\
\frac{\pi}{00} \\
0\end{array}$ & 㣽 & $\begin{array}{l}\stackrel{0}{0} \\
\text { on } \\
\stackrel{0}{0} \\
\stackrel{0}{0} \\
\stackrel{1}{0} \\
0\end{array}$ & 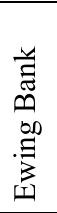 & 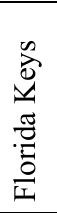 & 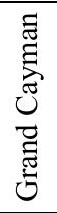 & 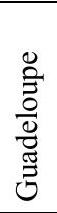 & 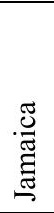 & 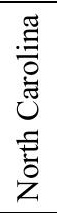 & 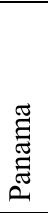 & 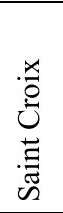 & \\
\hline L. canariensis & $x$ & & & & & & & & & $x$ & & & & & Schultz et al. (2015) \\
\hline L. colombiana ${ }^{(1)}$ & & & $x$ & & & & & & & & & & & & Camacho et al. (2019) \\
\hline L. crispata $^{(2)}$ & & & & $x$ & & & & & & $x$ & & & $x$ & & Camacho et al. (2019) \\
\hline L. declerckii & $x$ & & & & $x$ & & & $x$ & & $x$ & & & & $x$ & Schultz et al. (2015) \\
\hline L. delicata ${ }^{(3)}$ & $x$ & & & & & & $x$ & & & $x$ & & & & & $\begin{array}{l}\text { Schultz et al. (2015), } \\
\text { Camacho et al. (2019) }\end{array}$ \\
\hline L. dispersa ${ }^{(4)}$ & & & & $x$ & $x$ & & $x$ & & & & & $x$ & $x$ & & Camacho et al. (2019) \\
\hline L. guadeloupensis & & & & & & & & & & & & & & & Schultz et al. (2015) \\
\hline L. littlerorum & & & & & & & & & & & & & & & Schultz et al. (2015) \\
\hline L. schneideri ${ }^{(5)}$ & $x$ & & & & & & & & & & & & & $x$ & Schultz et al. (2015) \\
\hline L. $\operatorname{spWA} 02^{(6)}$ & $x$ & & & & & & & & & & & & & & Schultz et al. (2015) \\
\hline L. sp64(7) & & & & & & & & & & $x$ & & & & & Schultz et al. (2015) \\
\hline L. sp85 & & & & & & & & & & & & & & & Vieira et al. (2016) \\
\hline L. $\operatorname{sp} 86^{(8)}$ & & & & & & & & & & & & & & $x$ & Schultz et al. (2015) \\
\hline L. tortugensis $^{(9)}$ & & & & & & $x$ & & & & & & & & & Camacho et al. (2019) \\
\hline L. variegata & & $x$ & $x$ & $x$ & & $x$ & $x$ & $x$ & $x$ & $x$ & $x$ & & & & Vieira et al. (2016) \\
\hline
\end{tabular}

This article is protected by copyright. All rights reserved 
510 TABLE 2. Descriptions of new Lobophora species and L. variegata from the Greater Caribbean.

\section{Lobophora agardhii sp.nov. Payri \& C.W.Vieira}

Figs. 3J, 4A

Description: Thallus coarse, predominantly crustose, dark brown in color, leatherlooking. Margin entire. Attached to substratum by scattered ventral rhizoids. Thallus of single to double-cell-layered medulla, 2-cell-layered cortex on dorsal and ventral side, 211-245 $\mu \mathrm{m}$ thick and composed of 5 to 6-cell-layers. Mitochondrial-encoded $\operatorname{cox} 3$ sequence $=$ GenBank accession MN240122.

Holotype (designated here): NOU 201772 [CP15811]

Type locality: Rocher Alizé (18.1173, -63.226333), Saint Martin, Leeward Islands, Lesser Antilles, West Indies

Habitat: Growing on Avrainvillea nigricans on coarse sand bottom $3 \mathrm{~m}$ deep, forming a sleeve around the stipe.

Distribution: Bermuda, Saint Martin.

Etymology: Named after the Swedish botanist, phycologist, and taxonomist Jacob Georg Agardh (December 8, 1813 - January 7, 1901) who described the genus Lobophora.

Specimens examined: Rocher Alizé, Saint Martin, May 7, 2015 leg. C. Payri (CP 15811).

Remarks: This species corresponds to Lobophora spWA02 (BDA3424, Bermuda) of Schultz et al. (2015)

\section{Lobophora dickiei sp. nov. Payri \& C.W.Vieira}

Figs. 3, $\mathrm{C}$ and $\mathrm{K}, 4 \mathrm{C}$

Description: Thallus flabellate, to $3 \mathrm{~cm}$ wide and $2.5 \mathrm{~cm}$ tall, procumbent to crustose, orange to light green radial gradient in color speckled with darker small spots. Attached to substratum by numerous ventral rhizoids. Margin entire. Thallus of single-cell-layered medulla, 2 and 1-cell-layered cortex on the dorsal and ventral side, respectively, 129-142 $\mu \mathrm{m}$ thick and composed of 4-5 cell-layers. Distinguished from related species by its orange-green color speckled with darker small spots and procumbent habit. Mitochondrial-encoded $\operatorname{cox} 3$ sequence $=$ GenBank accession 
MN240119.

Holotype (designated here): NOU 201781 [CP15473]

Type locality: Trou du Diable (13.860833, -61.074167), Saint Lucia, Windward Islands, Lesser Antilles, West Indies

Habitat: Growing on hard substrate; corals and reef wall on shallow habitats.

Distribution: Curaçao, Saint Lucia.

Etymology: named after the Scottish botanist who specialized in algae, George Dickie (December 21, 1812 - June 10, 1882), and described Lobophora obscura, as Zonaria obscura.

Specimens examined: Rocroy Val de l'Orge, Guadeloupe, October 10, 2014, leg.

C. Payri (IRD 11142); Case Pilote, Martinique, April 24, 2015, leg. C. Payri (CP 15086); Trou du Diable, Saint Lucia, April 30, 2015, leg. C. Payri (CP 15456); Trou du Diable, Saint Lucia, April 30, 2015, leg. C. Payri (CP 15473); Wallibou, Saint Vincent, April 26, 2015, leg. C. Payri (IRD11175); Château Bel Air Bay, Saint Vincent, April 26, 2015, leg. C. Payri (CP 15178).

Remarks: This species corresponds to Lobophora spWA01 (STX0024, Saint Croix) of Schultz et al. (2015) and L. sp86 of Vieira et al. (2016) 


\section{Lobophora lamourouxii sp. nov. Payri \& C.W.Vieira}

Figs. 3, E and L, 4D

Description: Large circular thallus, to $5 \mathrm{~cm}$ wide and 2.5 tall, predominantly procumbent, distal margin free, light green transparent in color. Attached to substratum by ventral rizhoids. Margin entire. Thallus of single-cell-layered medulla, 1-cell-layered cortex on the dorsal and ventral side, respectively, 110-124 $\mu \mathrm{m}$ thick and composed of 3-4-cell-layers. Distinguished from related species by its translucent blades and prostrate growth form. Mitochondrial-encoded cox3 sequence $=$ GenBank accession MN240030.

\section{Holotype (designated here): NOU 201665 [IRD11176, CP15166]}

Type locality: Wallibou (13.333, -61.221617), Saint Vincent, Windward Islands, Lesser Antilles, West Indies

Habitat: Growing on shallow rocky shore.

Distribution: Curaçao, Guadeloupe, Saint Vincent.

Etymology: named after the French biologist and naturalist Jean Vincent Félix Lamouroux (May 3, 1779 - March 26, 1825) who described the first species of Lobophora, Lobophora variegata, as Dictyota variegata.

Specimens examined: Wallibou, Saint Vincent, April 26, 2015, leg. C. Payri

(IRD11176); Rocher La Perle, Guadeloupe, April 23, 2015, leg. C. Payri

(IRD11168); Canoa, Curaçao, February 11, 2017, leg. C. Vieira (CWV0816).

Remarks: This species corresponds to Lobophora spWA03 (PC0143252,

Guadeloupe) of Schultz et al. (2015) and L. sp64 of Vieira et al. (2016)

\section{Lobophora richardii sp. nov. C.W.Vieira \& Payri}

Figs. 3, $\mathrm{F}$ and $\mathrm{M}, 4 \mathrm{E}$

Description: Thallus circular, to $10 \mathrm{~cm}$ wide, predominantly erect and ruffled, light green in color with darker small spots forming concentric lines. Attached to the substratum by basal mound of rhizoids. Margin entire. Thallus of single-cell-layered medulla, 3-cell-layered cortex on the dorsal and ventral side, 215-248 $\mu \mathrm{m}$ thick and composed of 7-cell-layers. Distinguished from related species by its ruffled growth form and light green color with darker small spots forming concentric lines. Mitochondrial-encoded cox3 sequence $=$ GenBank accession MN240034. 
Holotype (designated here): NOU 201785 [IRD11170, CP15127]

Type locality: Diamant $(14.6579,-61.15755)$, Martinique, Windward Islands, Lesser Antilles, West Indies

Habitat: Growing in deep water (30 m deep) with other large algae, fixed on sand-covered substrate.

Distribution: Martinique, Curaçao.

Etymology: named after the French botanist and botanical illustrator Louis Claude Marie Richard (September 19, 1754 - June 6, 1821) who collected the type specimen of Lobophora variegata.

Specimens examined: Diamant, Martinique, April 25, 2015, leg. C. Payri (IRD 11170); Klein Curaçao, Curaçao, February 9, 2017, leg. C. Vieira (CWV0541).

Remarks: This species corresponds to L. sp85 of Vieira et al. (2016) 


\section{Lobophora setchellii sp. nov. C.W.Vieira \& Payri}

Figs. 3, I and N, 4F

Description: Thallus small, to $1 \mathrm{~cm}$ wide, predominantly procumbent, light green in color. Attached to substratum by basal mound of rhizoids. Thalli overlapping forming

a mat. Margin entire. Thallus of single-cell-layered medulla, 2 and 1-cell-layered cortex on the dorsal and ventral side, respectively, 123-139 $\mu \mathrm{m}$ thick and composed of 4-cell-layers. Mitochondrial-encoded cox3 sequence $=$ GenBank accession MN240043.

Holotype (designated here): NOU 206223 [CP15174]

Type locality: Château Bel Air Bay (13.29955, -61.2483), Saint Vincent, Windward Islands, Lesser Antilles, West Indies

Habitat: Growing on bedrock and epiphytic on calcareous red algae.

Distribution: Saint Vincent, Curaçao.

Etymology: named after the American phycologist William Albert Setchell (April 15, 1864 - April 5, 1943) who collected the type specimen of Lobophora pacifica. Specimens examined: Château Bel Air Bay, Saint Vincent, April 26, 2015, leg. C. Payri (CP15174); Klein Curaçao, Curaçao, February 9, 2017, leg. C. Vieira (CWV0642).

Remarks: This species corresponds to $L$. sp10 of Vieira et al. (2016).

\section{Lobophora variegata (J.V. Lamour.) Womersley ex E.C. Oliveira}

Figs. 3, G and $0,4 \mathrm{H}$

Basionym: Dictyota variegata J.V.Lamour.

Diagnosis: Thallus fan shaped, erect, with a basal mound of rhizoids and in some individuals a rudimentary stipe, to $8 \mathrm{~cm}$ wide and $6 \mathrm{~cm}$ tall, forming clusters of ruffled yellowish brown to dark brown and green blades. Blades 112-197 $\mu \mathrm{m}$ thick, composed of 5-7 cell layers, a single medullary layer and cortex of two to three cell layers on the dorsal and ventral sides. Mitochondrial-encoded cox3 sequence $=$ GenBank accession KU364222, KU364223, KU353160, KX061443, MN240037- MN240037; chloroplast-encoded $r b c \mathrm{~L}$ sequences KU364182, KU364183, KU352998, KU352999, KX061445; chloroplast-encoded psbA 
sequences and KU364269, KU364270, KU352855, KU352856, KX061444.

Habitat: Lobophora variegata occurs in shallow water, to $7 \mathrm{~m}$ depth on hard substratum or coral rubble mixed among numerous other algae including Dictyota J.V.Lamour., Sargassum J.Agardh, Jania J.V.Lamour. and Caulerpa J.V.Lamour., and was also found growing on the holdfast and basal branches of Sargarassum pteropleuron Grunow, gorgonian corals and Thalassia testudiunum Banks ex K.D.Koenig leaves in the Florida Keys and sponges in the Martinique.

Type specimen: CN C7F100 (CN, Herbarium of the Université de Caen, France) Type locality: 'Antilles', Caribbean Sea; presumably Guadeloupe (see Vieira et al. 2016).

Distribution: Bahamas, Dominican Republic, Florida, Guadeloupe, Jamaica, Martinique, Mexico, Saint Martin.

Specimens examined: Pointe de la Baleine, Martinique, April 24, 2015, leg. C. Payri (CP15095); Ile de Tintamare, Saint Martin, May 6, 2015, leg. C. Payri (CP15729); Ile de Tintamare, Saint Martin, May 6, 2015, leg. C. Payri (CP15730); Ile de Tintamare, Saint Martin, May 6, 2015, leg. C. Payri (CP15731); El Portillo, Dominican Republic, July 1, 2016, leg. E. Serrão (DR01); El Portillo, Dominican Republic, July 1, 2016, leg. E. Serrão (DR02; El Portillo, Dominican Republic, July 1, 2016, leg. E. Serrão (DR03).

Specimens from previous studies: MW11719, Bahamas (Vieira et al. 2016); MW11793, Bahamas (Vieira et al. 2016); LAF6912, Bahamas (Vieira et al. 2016); LAF6914, Florida (Vieira et al. 2016); IRD11140, Guadeloupe (Vieira et al. 2016); HV939, Jamaica (Vieira et al. 2016). 
TABLE 3. Comparison of morphological characters among species of Lobophora from the Greater Caribbean.

\begin{tabular}{|c|c|c|c|c|c|c|c|c|}
\hline & $\begin{array}{l}\text { L. agardhii } \\
\text { sp. nov. }\end{array}$ & L. canariensis & L. caboverdeana & L. colombiana & L. crispata & L. declerckii & L. delicata & $\begin{array}{l}\text { L. dickiei } \\
\text { sp. nov. }\end{array}$ \\
\hline \multicolumn{9}{|l|}{ Thickness } \\
\hline Average & $228.3 \pm 10.8$ & $102 \pm 8$ & $183.7 \pm 13.7$ & 86 & 112 & $\mathrm{~N} / \mathrm{A}$ & 58 & $134.0 \pm 5.4$ \\
\hline Min-Max & $211-245$ & $80-112$ & $170-215$ & $74-94$ & $100-122$ & $55-85$ & $48-65$ & $129-142$ \\
\hline \multicolumn{9}{|l|}{ Number of cells } \\
\hline Average & 6 & 5 & 8 & 5 & 6 & $\mathrm{~N} / \mathrm{A}$ & 3 & 5 \\
\hline Min-Max & $5-6$ & 5 & $7-9$ & 5 & $5-7$ & $3-5$ & $3-4$ & $4-5$ \\
\hline \multicolumn{9}{|c|}{ Number of dorsal cells } \\
\hline Average & 2 & 2 & 4 & 2 & 2 & $\mathrm{~N} / \mathrm{A}$ & 1 & 2 \\
\hline Min-Max & 2 & 2 & $3-4$ & 2 & $2-3$ & $1-2$ & 1 & 2 \\
\hline \multicolumn{9}{|c|}{ Number of ventral cells } \\
\hline Average & 2 & 2 & 3 & 2 & 2 & $\mathrm{~N} / \mathrm{A}$ & 1 & 2 \\
\hline Min-Max & 2 & 2 & $3-4$ & 2 & $2-3$ & $1-2$ & 1 & $1-2$ \\
\hline \multicolumn{9}{|l|}{ Medulla length } \\
\hline Average & $128.0 \pm 14.7$ & $79 \pm 12$ & $70.0 \pm 5.0$ & 80 & 76 & N/A & 70 & $86.8 \pm 8.3$ \\
\hline Min-Max & $195-147$ & $60-100$ & $65-75$ & $62-92$ & $58-101$ & $62-100$ & $59-81$ & $76-103$ \\
\hline \multicolumn{9}{|l|}{ Medulla height } \\
\hline Average & $92.9 \pm 13.1$ & $45 \pm 6$ & $60.0 \pm 7.1$ & 39 & 49 & N/A & 26 & $60.4 \pm 7.8$ \\
\hline Min-Max & $77-119$ & $30-54$ & $50-75$ & $34-49$ & $32-63$ & $30-50$ & $20-34$ & $49-69$ \\
\hline \multicolumn{9}{|l|}{ Medulla width } \\
\hline Average & $61.5 \pm 3.9$ & $33 \pm 4$ & $37.0 \pm 6.3$ & 25 & 23 & $\mathrm{~N} / \mathrm{A}$ & 27 & $65.7 \pm 3.1$ \\
\hline Min-Max & $56-64$ & $30-40$ & $30-50$ & $20-28$ & $20-26$ & $25-45$ & $25-29$ & $59-68$ \\
\hline \multicolumn{9}{|l|}{ Dorsal height } \\
\hline Average & $69.4 \pm 6.2$ & $30 \pm 3$ & $70.7 \pm 5.3$ & $\mathrm{~N} / \mathrm{A}$ & $\mathrm{N} / \mathrm{A}$ & $\mathrm{N} / \mathrm{A}$ & $\mathrm{N} / \mathrm{A}$ & $42.6 \pm 4.1$ \\
\hline Min-Max & $60-80$ & $26-34$ & $30-80$ & $\mathrm{~N} / \mathrm{A}$ & N/A & $15-22 *$ & N/A & $38-47$ \\
\hline
\end{tabular}

This article is protected by copyright. All rights reserved 


\begin{tabular}{|c|c|c|c|c|c|c|c|c|c|}
\hline & Average & $66.0 \pm 5.6$ & $27 \pm 3$ & $53.0 \pm 9.6$ & $\mathrm{~N} / \mathrm{A}$ & $\mathrm{N} / \mathrm{A}$ & $\mathrm{N} / \mathrm{A}$ & N/A & $31.0 \pm 7.4$ \\
\hline & Min-Max & $57-75$ & $20-32$ & $40-70$ & $\mathrm{~N} / \mathrm{A}$ & N/A & $14-20^{*}$ & N/A & $20-37$ \\
\hline \multicolumn{10}{|c|}{ Thallus } \\
\hline & Growth-form & crustose & $\begin{array}{l}\text { crustose to } \\
\text { decumbent }\end{array}$ & crustose & decumbent & decumbent & decumbent & $\begin{array}{c}\text { crustose, procumbent, } \\
\text { deceumbent }\end{array}$ & procumbent, crustose \\
\hline & Color & dark brown & orange-brown & light brown & brown & dark brown & light green & translucent light green & organge to light green \\
\hline Ref & erences & This study & Vieira et al. 2016 & This study & Camacho et al. 2019 & Camacho et al. 2019 & Schultz et al. 2015 & Camacho et al. 2019 & This study \\
\hline
\end{tabular}

N/A: not available; * sum of cortex and "subcortex" in Schultz et al. 2015

This article is protected by copyright. All rights reserved 
TABLE 3. Continued

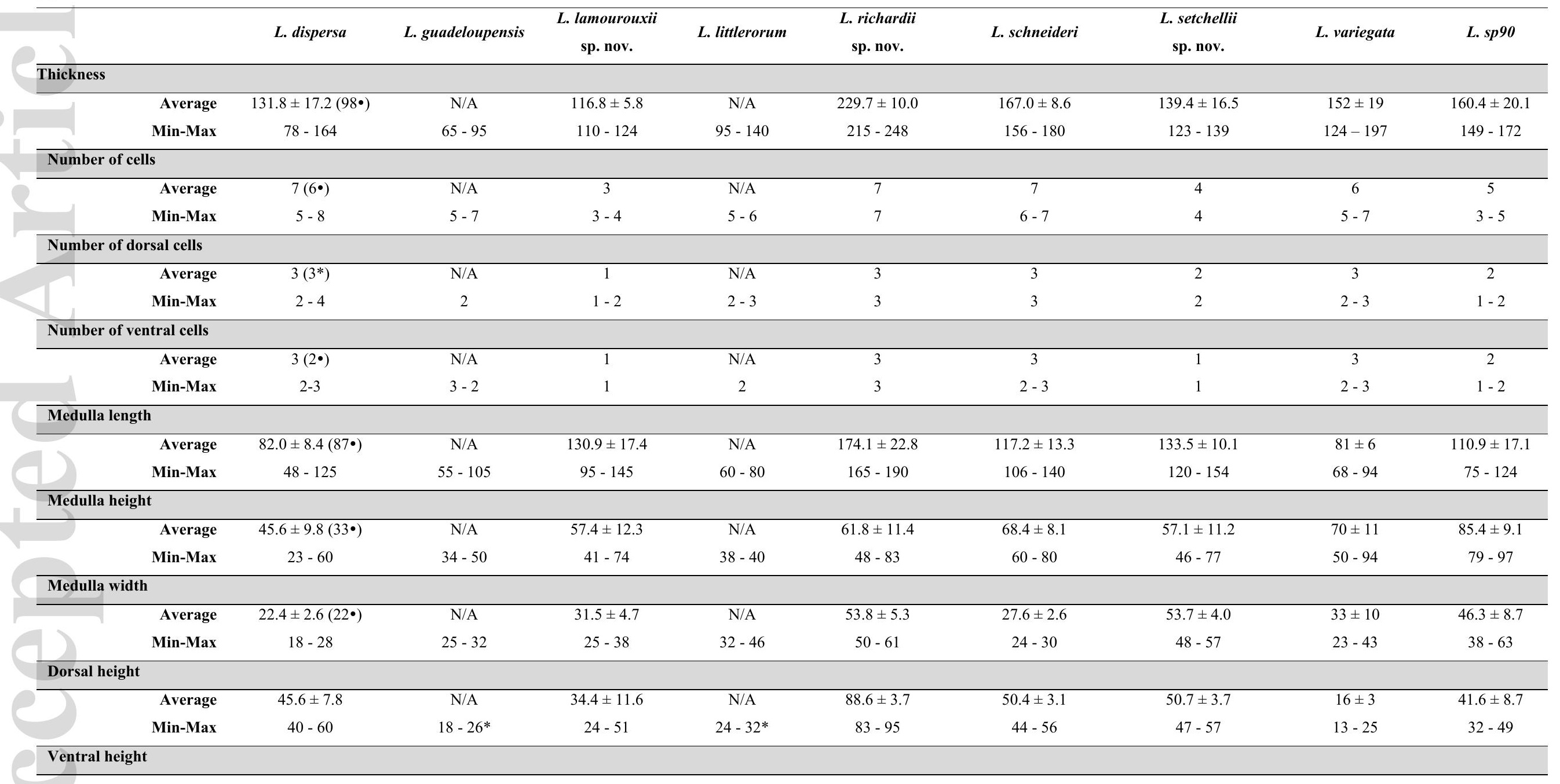

This article is protected by copyright. All rights reserved 


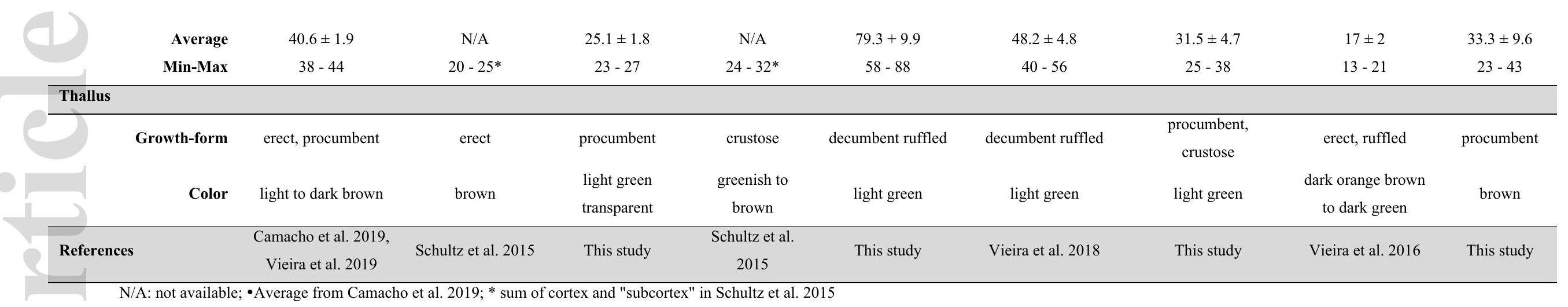

N/A: not available; •Average from Camacho et al. 2019; * sum of cortex and "subcortex" in Schultz et al. 2015

This article is protected by copyright. All rights reserved 
TABLE 4. Comparison of morphological and ecological features of the Greater Caribbean Lobophora species.

\begin{tabular}{|c|c|c|c|c|c|c|c|}
\hline & Morphology & Habitat & Depth & Exposition & Substrate & $\begin{array}{l}\text { Grazing } \\
\text { intensity }\end{array}$ & Abundance \\
\hline L. aghardii sp. nov. & Crustose & Sand bottom & $0-8$ & $\mathrm{~N} / \mathrm{A}$ & Rock, seaweed & $\mathrm{N} / \mathrm{A}$ & Low \\
\hline L. canariensis & Crustose/Decumbent & Coral reef & $0-36$ & Medium - Low & Rock & N/A & Low \\
\hline L. caboverdeana & Crustose & Sargassum bed & 0 & High & Rock, seaweed & $\mathrm{N} / \mathrm{A}$ & Low \\
\hline L. colombiana & Decumbent & Coral reef & $0-20$ & Medium - Low & Rock & N/A & N/A \\
\hline L. crispata & Fasciculate/Stipitate & Coral reef & $1-20$ & N/A & Rock & N/A & N/A \\
\hline L. declerckii & Conk-like/Decumbent & Coral reef & $12-36$ & Low & Rock & Medium & High \\
\hline L. delicata & Procumbent & Coral reef & $0-14$ & Low & Rock & N/A & Low \\
\hline L. dickiei sp. nov. & Crustose/Procumbent & Coral reef & $5-20$ & $\mathrm{~N} / \mathrm{A}$ & Dead coral & N/A & Low \\
\hline L. dispersa & Procumbent & Coral reef & $1-90$ & Low & $\begin{array}{l}\text { Rock, rhodolith, } \\
\text { dead coral }\end{array}$ & N/A & High \\
\hline L. guadeloupensis & Fasciculate & Seagrass bed & $6-136$ & High & Rock, sand & High & $\mathrm{N} / \mathrm{A}$ \\
\hline L. lamourouxii sp. nov. & Procumbent & Rocky shore & $5-80$ & $\mathrm{~N} / \mathrm{A}$ & Rock, CCA & $\mathrm{N} / \mathrm{A}$ & $\mathrm{N} / \mathrm{A}$ \\
\hline L. littlerorum & Crustose & Rocky shore & $0-8$ & High & Rock, live coral & $\begin{array}{l}\text { Moderate } \\
\text {-high }\end{array}$ & Low \\
\hline L. richardii sp. nov. & Decumbent/Fasciculate & Seaweed bed & $25-30$ & Low & Sand & $\mathrm{N} / \mathrm{A}$ & Low \\
\hline L. schneideri & Fasciculate & Seagrass bed & $0-12$ & Low & Rock & Medium & Low \\
\hline L. variegata & Decumbent/Fasciculate & Seagrass bed & $8-10$ & Low & Rock & $\begin{array}{l}\text { Moderate } \\
\text {-high }\end{array}$ & Medium \\
\hline L. tortugensis & Fasciculate & Rhodolith bed & $60-90$ & Low & Rhodololith & Low & N/A \\
\hline L. setchellii sp. nov. & Crustose/Procumbent & Coral reef & $5-20$ & Low & Rock, CCA & N/A & Low \\
\hline$L . \operatorname{sp90}$ & Crustose/Procumbent & Coral reef & 10 & Low & Rock & Medium & Low \\
\hline
\end{tabular}


TABLE S1. Information on the sampling campaigns and countries.

TABLE S2. Information on the Lobophora specimens collected in the Greater Caribbean.

Figure S1. Phylogenetic tree of Lobophora species using maximum likelihood method based on cox3 sequences. Values shown at each node represent bootstrap supports. Two species from the Greater Caribbean were not identified in our study, L. crispata, for which no cox3 sequences are available, and L. tortugensis indicated by a star in the tree.

This article is protected by copyright. All rights reserved 


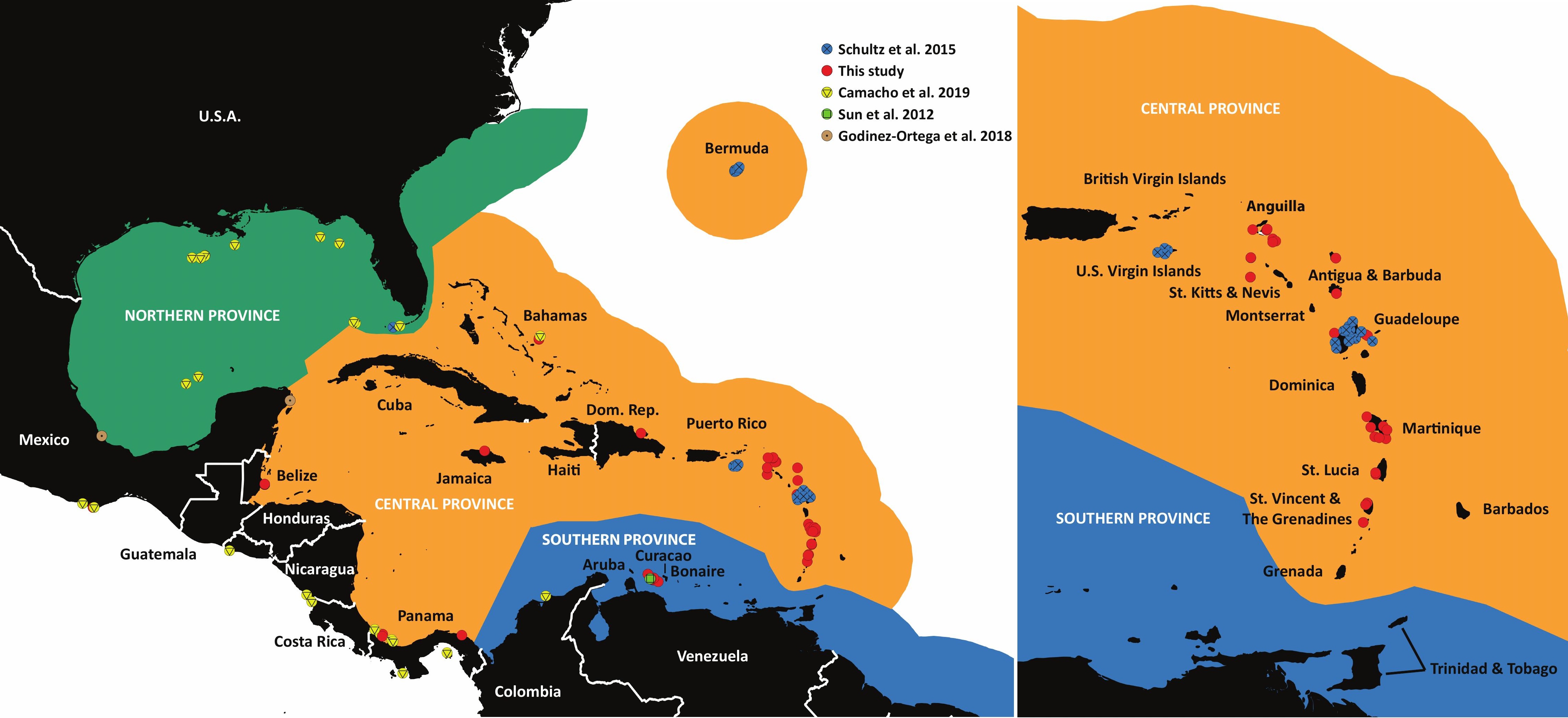




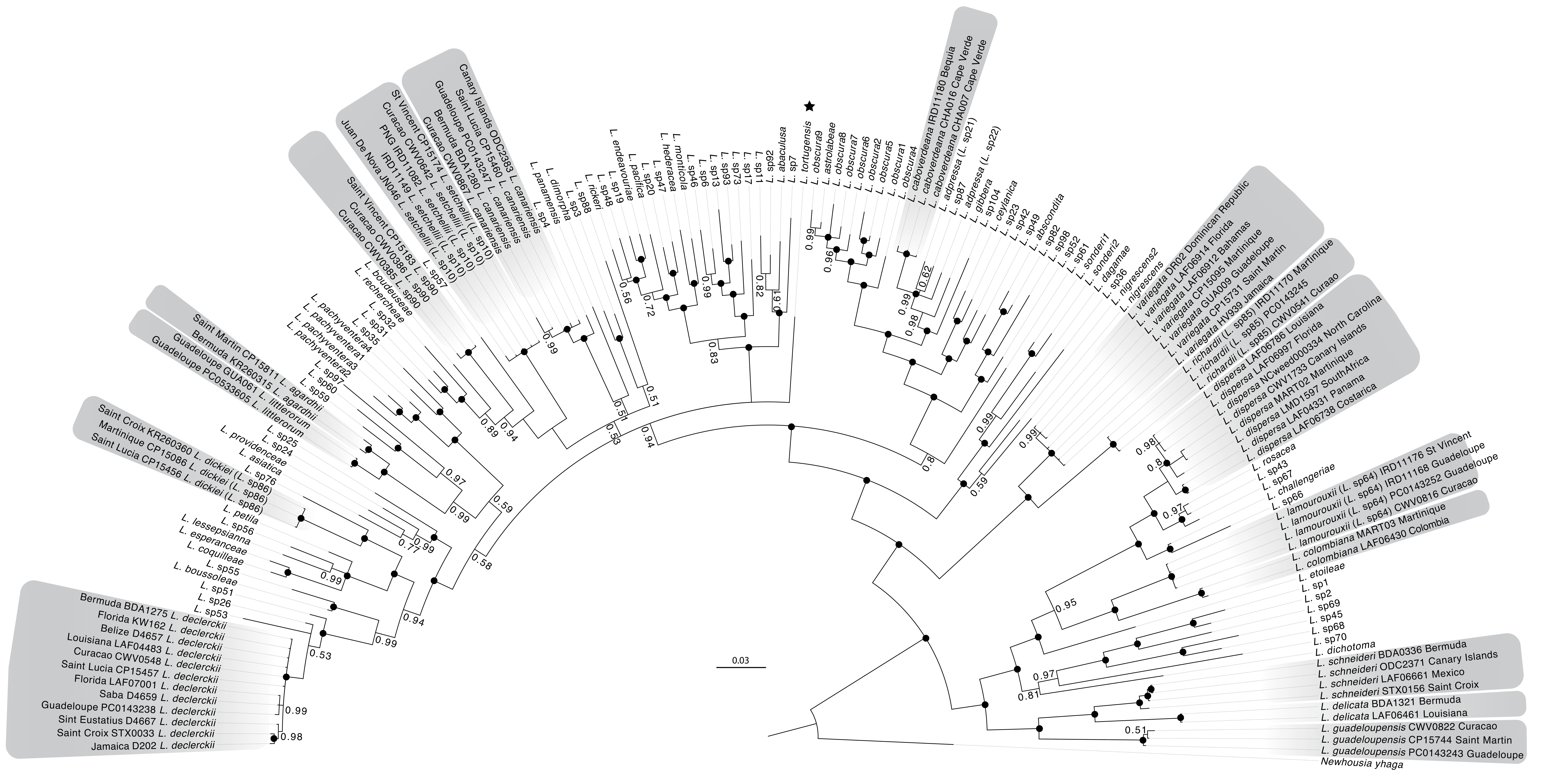




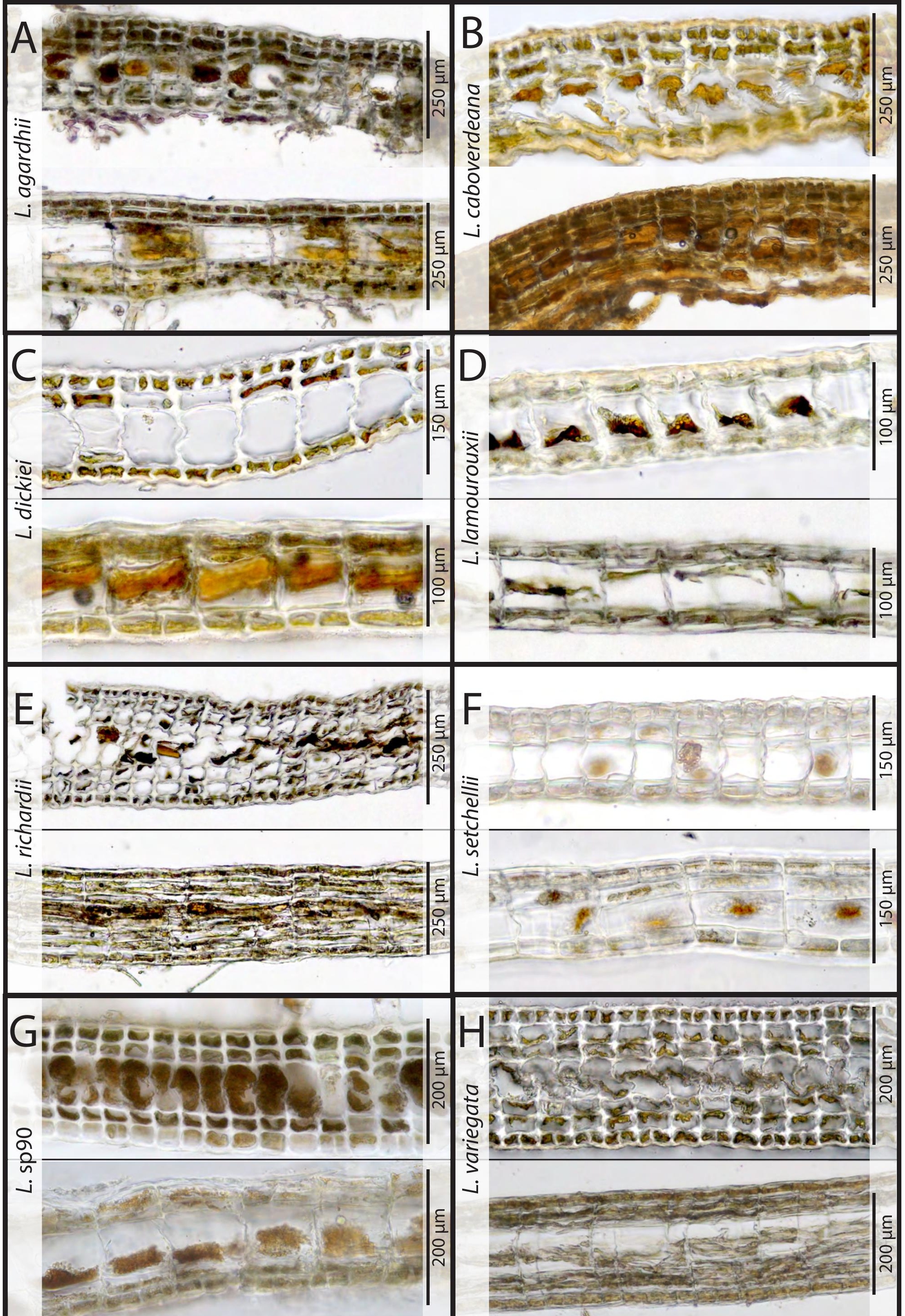




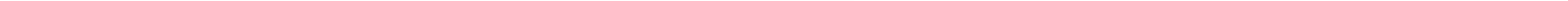



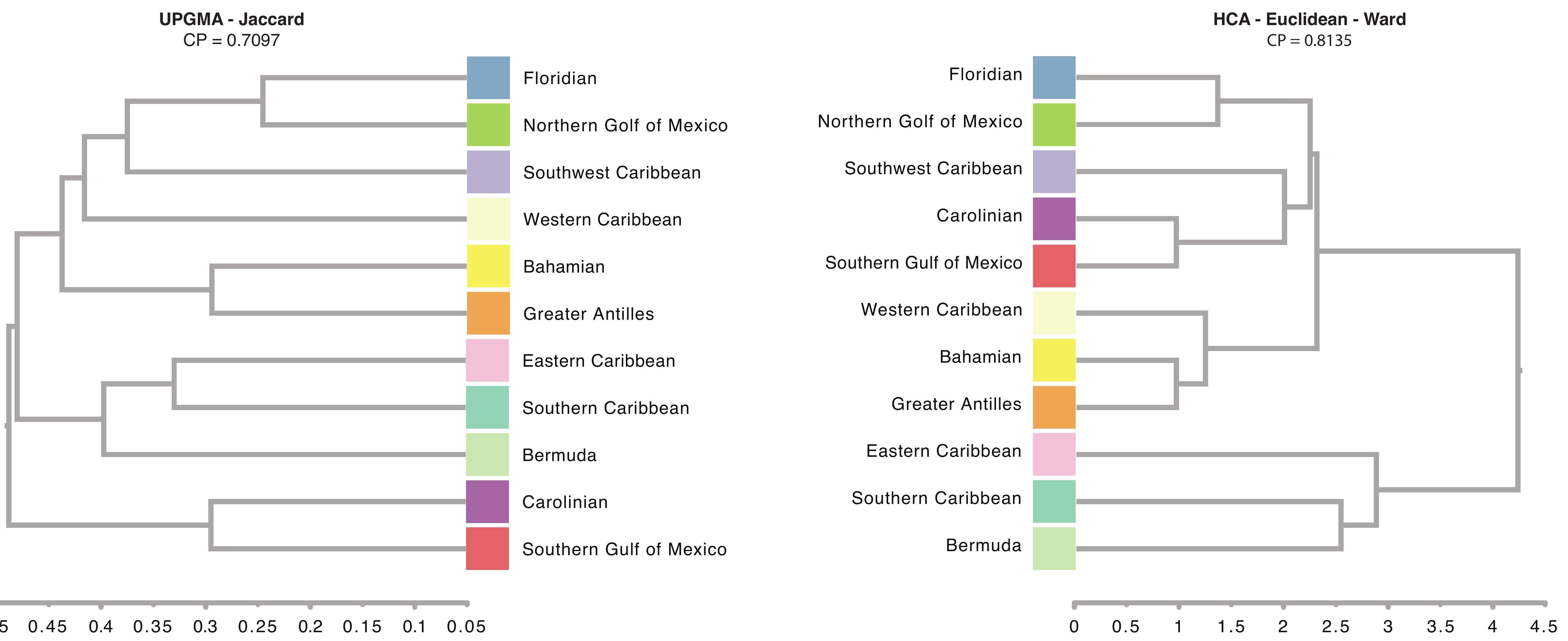